\title{
The effect of by-product inclusion level on milk production, nutrient digestibility and excretion, and rumen fermentation parameters in lactating dairy cows offered a pasture-based diet
}

\author{
S. J. Whelan, ${ }^{*}$ W. Carey, $†$ T. M. Boland, $\dagger^{1}$ M. B. Lynch, $†$ A. K. Kelly, $†$ G. Rajauria, $†$ and K. M. Pierce $†$ \\ ${ }^{*}$ AHDB Dairy, Agriculture and Horticulture Development Board, Stoneleigh Park, Kenilworth, Warwickshire, CV8 2TL United Kingdom \\ †School of Agriculture and Food Science, University College Dublin Lyons Farm, Celbridge, Co. Kildare, Ireland
}

\begin{abstract}
The objective of this study was to investigate the effects of replacing barley and soybean meal with increasing levels of by-products on production, digestive, and metabolic parameters in early-mid lactation dairy cows offered perennial ryegrass-based pasture. Forty-eight (32 multiparous and 16 primiparous) dairy cows that were $64 \pm 24 \mathrm{~d}$ in milk were assigned to 1 of 4 pasture-based dietary treatments $(\mathrm{n}=12)$ in a randomized block design experiment that ran for 70 d. Treatments consisted of a perennial ryegrass-based pasture and 1 of 4 supplementary concentrates: BP35, BP55, BP75, and BP95 containing 35, 55, 75, and $95 \%$ by-products, respectively, in the concentrate on a dry matter basis. The by-products used were soyhulls, dried distillers grains, and palm kernel extract in equal proportions. Barley and soybean meal were replaced as by-product inclusion level increased. In this study, intakes of pasture dry matter $(15.7 \mathrm{~kg})$ and total dry matter $(21.1 \mathrm{~kg})$ were not affected by treatment. Similarly, milk production parameters (milk yield, milk composition, somatic cell count, and urea) were not different between treatments. Unsaturated fatty acids were lower in the milk of cows offered BP35 and BP55 compared with those offered BP75 and BP95. Concentrations of $\beta$-hydroxybutyrate, nonesterified fatty acids, and other blood metabolites were within normal range and did not differ between treatments, and cow body condition score and body weight were also not different. Equally, $\mathrm{N}$ was unaffected by diet. Blood urea $\mathrm{N}$ was lower in the BP75 group compared with BP35. This study demonstrated that barley and soybean meal can be replaced with soyhulls, dried distillers grains, and palm kernel extract without affecting milk production, digestive, or metabolic parameters in dairy cows offered a pasture-based diet.
\end{abstract}

Received June 13, 2016.

Accepted October 31, 2016.

${ }^{1}$ Corresponding author: tommy.boland@ucd.ie
Key words: dairy cow, by-products, grazing, milk production, nutrient excretion

\section{INTRODUCTION}

One of the fundamental advantages of ruminant production systems is the ability to convert low-quality feedstuffs into meat and milk that are digestible by humans. This has been an advantage to Ireland as well as other temperate regions of the world where high yields of quality pasture are achievable, allowing for relatively low cost systems of dairy production (Dillon et al., 2008). However, pasture growth is seasonal and it can be difficult to achieve sufficient intake to support the nutrient requirements of the dairy cow, particularly those cows yielding in excess of $25 \mathrm{~kg}$ ( $2 \mathrm{~kg}$ of fat and protein)/d (Purcell et al., 2016). In these instances, dairy cows require supplementation to complement grazed grass, but the type of supplement offered may have an important bearing on both the economic and environmental performance of the dairy farm.

Cereals and soybean meal are commonly used to bridge the gap between nutrient supplied by pasture and that required by the dairy cow. However, supply and demand forces of the international market have seen large fluctuations in the price of cereals and soybean meals (Sinclair et al., 2014), creating uncertainty in dairy production systems that are more reliant on these feeds. To this end, the dairy industry has been exploring the use of alternative by-products such as palm kernel expeller (PKE, Kolver, 2006; Dias et al., 2008), soyhulls (SH, Ipharraguerre et al., 2002; Aikman et al., 2006), and dried distillers grains (DDGS, Schingoethe et al., 2009; Abdelqader and Oba, 2012) for use in the diet of the lactating dairy cow. These feeds are advantageous for ruminant diets compared with cereals and soybean meal as they are not utilizable as human foodstuffs and their use in pig and poultry diets is limited, reducing competition for these feeds. However, the perceived negative effects of by-products on animal performance have limited their use, with 
many recommendations quoting low inclusion levels in the diet (Ewing, 1998).

Irish dairy farmers operate predominantly pastoralbased, seasonal-calving milk production systems, and consequently a large portion of nutrient losses (nitrogen, N) occur when animals are outdoors grazing (Hyde et al., 2003; Casey and Holden, 2005). Additionally, modern dairy production systems operate within set environmental standards (S.I., 2010) with inputs of N to the farm system often limited. Because PKE and DDGS contain relatively high concentrations of $\mathrm{N}$, it will be important to quantify any changes in the excretion of $\mathrm{N}$ as a result of increased inclusion levels of these feed ingredients.

Limited data are available on the use of these byproducts in pasture-based dairy production systems and less still where combinations of by-products are offered. Therefore, the objective of this study was to investigate the effects of replacing barley and soybean meal with increasing levels of by-products on production, digestive, and metabolic parameters in early-mid lactation dairy cows offered perennial ryegrass-based pasture.

\section{MATERIALS AND METHODS}

All procedures described in this experiment were approved by the animal research ethics committee at University College Dublin and conducted under experimental license from the Irish Medicines Board under European directive 2010/63/EU and S.I. no. 543 of 2012.

Thirty-two multiparous and 16 primiparous dairy cows (Bos taurus strain Holstein Friesian) were selected from the spring calving dairy herd at University College Dublin Lyons Research Farm, Celbridge, Co. Kildare, Ireland $\left(53^{\circ} 17^{\prime} 56^{\prime \prime} \mathrm{N}, 6^{\circ} 32^{\prime} 18^{\prime \prime} \mathrm{W}\right)$. The cows were then blocked on DIM (means \pm SD; $64 \pm 24$ ) and assigned to 1 of 4 pasture-based dietary treatments $(\mathrm{n}=12)$ in a randomized block design experiment that ran for 70 d. Blocks were balanced for parity, pre-experimental milk yield, and BCS. Treatments consisted of a perennial ryegrass based pasture and 1 of 4 supplementary concentrates: BP35, BP55, BP75, and BP95 containing $35,55,75$, and $95 \%$ by-products in the concentrate on a DM basis. The by-products used were SH, DDGS (dried distillers grains with solubles), and PKE in equal proportions on a DM basis (Table 1). To formulate the BP55 ration, $2 \mathrm{~kg}$ of $\mathrm{BP} 35$ and $1 \mathrm{~kg}$ of BP95 were mixed at each milking, whereas BP75 was formulated by mixing $1 \mathrm{~kg}$ of BP35 and $2 \mathrm{~kg}$ of BP95 at each milking. Mixing was achieved using 2 separate feed lines in an automatic, in-parlor concentrate dispensing system linked to cow electronic identification (FeedRite, Dairy Master Ltd., Kerry, Ireland). The treatments were formulated to be iso-nitrogenous $(16 \% \mathrm{CP})$.

Animals were grazed in a single group and were offered fresh allocations $(10 \mathrm{~kg}$ of $\mathrm{DM} / \mathrm{cow})$ of pasture twice daily (20 kg of DM/d, total). Pregrazing herbage mass was determined using the quadrat and shears method. Briefly, an area $\left(0.25 \mathrm{~m}^{2}\right)$ was cut using a handheld shears (Gardena Accu 90, Gardena GmbH, Ulm, Germany) to a height of $4 \mathrm{~cm}$ at 6 random locations throughout the paddock. Each $0.25 \mathrm{~m}^{2}$ of grass was then collected and weighed; a sample of pasture was also taken for determination of DM and routine chemical analysis (Table 1). Average pregrazing herbage mass was $1,839 \pm 174 \mathrm{~kg}$ of $\mathrm{DM} /$ ha, whereas postgrazing herbage mass was $485 \pm 147 \mathrm{~kg}$ of $\mathrm{DM} /$ ha.

\section{Data and Sample Collection}

Animals were milked twice daily at 0700 and $1600 \mathrm{~h}$ with milk output and milk sampling facilitated using a milk metering and sampling system (Weighall, Dairy Master Ltd.). Samples of milk were taken once weekly during Wednesday (p.m.) and Thursday (a.m.) milking and pooled on a per cow basis according to yield. Body weight and BCS were determined at the beginning and the end of the experimental period. Body weight was measured using a weigh cell (Tru-Test Weighing Systems, Auckland, New Zealand) located in the dairy facility, whereas BCS was determined using a scale of 1 to 5 with increments of 0.25 according to Edmonson et al. (1989).

Blood samples were collected by jugular venipuncture once weekly following am milking. Samples for the determination of nonesterified fatty acids (NEFA), and BHB, bilirubin, urea N, P, gamma glutamyl transferase (GGT), and glutamate dehydrogenase (GLDH) were collected into a 10-mL Vacutainer (REF 367896, BDPlymouth, Plymouth, UK). Samples were allowed to clot for $24 \mathrm{~h}$ at $4^{\circ} \mathrm{C}$ before centrifuging at $2,100 \times g$ for 20 min at $4^{\circ} \mathrm{C}$ for extraction of serum. Blood samples for glucose were harvested into a 4-mL gray-top Vacutainer (REF 368921, BD-Plymouth) and centrifuged immediately postsampling at 2,100 $\times g$ for $20 \mathrm{~min}$ at $4^{\circ} \mathrm{C}$ for extraction of plasma. Samples of serum and plasma were stored at $-20^{\circ} \mathrm{C}$ pending analysis.

Rumen fluid was harvested by an esophageal scoop (Flora Rumen Scoop, Prof-Products, Guelph, Canada) following am milking once weekly. Rumen fluid $\mathrm{pH}$ was measured immediately postsampling using a $\mathrm{pH}$ meter (Orion 3 Star pH, Thermo-Scientific, Waltham, MA). Samples were strained through 4 layers of cheesecloth, and a 4-mL subsample was drawn off and then mixed 
Table 1. Chemical composition of concentrates and pasture and ingredient inclusion rate of concentrates fed during the experiment ${ }^{1}$

\begin{tabular}{lrrr}
\hline Item & BP35 & BP95 & Pasture \\
\hline Chemical composition (\% of DM unless stated) & & & \\
DM (\% of fresh weight) & 89.1 & 88.5 & 18.0 \\
NDF & 27.2 & 50.8 & 40.2 \\
ADF & 12.8 & 25.2 & 19.9 \\
ADL & 2.1 & 4.4 & 6.0 \\
Starch & 28.2 & 3.7 & 2.7 \\
Water-soluble carbohydrates & 0.0 & 0.0 & 15.5 \\
CP & 16.8 & 17.3 & 16.7 \\
Ether extract & 4.2 & 6.4 & 3.5 \\
Ash & 6.7 & 7.5 & 8.9 \\
Gross energy (MJ/kg of DM) & 17.3 & 18.3 & 16.3 \\
Ingredient inclusion rate of concentrates & & & \\
Barley & 45.0 & 0.0 & \\
Soybean meal & 12.0 & 0.0 & \\
Distillers dried grain & 11.6 & 31.0 & \\
Palm kernel expeller & 11.6 & 31.0 & \\
Soybean hulls & 11.6 & 31.0 & \\
Molasses & 5.0 & 5.0 & \\
Calcined magnesite & 0.8 & 0.8 & \\
Salt & 0.7 & 0.7 & \\
Lime flour & 0.6 & 0.6 & \\
Monocalcium diphosphate & 0.2 & \\
Vitamin and mineral premix &
\end{tabular}

${ }^{1} \mathrm{BP} 35$ = ration containing $35 \%$ by-products; BP55 = ration containing $55 \%$ by-products, $2 \mathrm{~kg}$ of BP35 $+1 \mathrm{~kg}$ of BP95; BP75 = ration containing $75 \%$ by-products, $1 \mathrm{~kg}$ of BP35 $+2 \mathrm{~kg}$ of BP95; BP95 = ration containing $95 \%$ by-products.

${ }^{2}$ Vitamin and mineral premix contained $33.9 \% \mathrm{Ca}, 500 \mathrm{mg}$ of $\mathrm{Co} / \mathrm{kg}, 7,400 \mathrm{mg}$ of $\mathrm{Cu} / \mathrm{kg}, 2,000 \mathrm{mg}$ of I/kg, 130 $\mathrm{mg}$ of Se $/ \mathrm{kg}, 10,000 \mathrm{mg}$ of $\mathrm{Mg} / \mathrm{kg}, 25,000 \mathrm{mg}$ of $\mathrm{Zn} / \mathrm{kg}, 1,600,000 \mathrm{IU}$ of vitamin A/ $\mathrm{kg}, 400,000 \mathrm{IU}$ of vitamin $\mathrm{D}_{3} / \mathrm{kg}$, and $2,000 \mathrm{mg}$ of vitamin $\mathrm{E} / \mathrm{kg}$.

with $1 \mathrm{~mL}$ of $50 \%$ (wt/vol) trichloroacetic acid. Samples were then stored at $-20^{\circ} \mathrm{C}$ pending determination of VFA and $\mathrm{NH}_{3} \mathrm{~N}$ concentrations.

\section{Nitrogen Partitioning Study}

Nitrogen partitioning was determined during wk 5 of the study (92 \pm 24 DIM). To facilitate this, pasture DMI and diet DM digestibility were estimated for a period of $6 \mathrm{~d}$ using the n-alkane technique of Mayes et al. (1986). Briefly, animals were dosed with a paper bolus impregnated with $500 \mathrm{mg}$ of the n-alkane, n-dotriacontane (C32), for a period of $12 \mathrm{~d}$ following am and pm milking. On the last $6 \mathrm{~d}$, samples of the concentrates, pasture, milk, and feces were collected. Pasture samples were collected from the pasture allocation for am and pm using a handheld shears (previously described). These samples were immediately dried at $55^{\circ} \mathrm{C}$ for $48 \mathrm{~h}$ and pooled per study period. Concentrate samples were collected twice daily and stored at $-20^{\circ} \mathrm{C}$ pending analysis, whereas fecal samples were collected per rectum and immediately placed in a forced-air oven at $55^{\circ} \mathrm{C}$ for $72 \mathrm{~h}$ or until dry. Samples of milk were collected during am and pm milking, pooled according to production, and frozen at $-20^{\circ} \mathrm{C}$.

\section{Sample Analyses}

Dried samples of pasture, concentrate, and feces were ground in a hammer mill fitted with a 1-mm screen (Lab Mill, Christy Turner, Suffolk, UK). Neutral detergent fiber and ADF were determined using the method of Van Soest et al. (1991) adopted for use in the Ankom 220 Fiber Analyzer (Ankom Technology, Macedon, NY). The method included a thermo-stable $\alpha$-amylase and Na-sulfide, but residual ash was not determined. Acid detergent lignin was determined following ADF determination by soaking the sample in $72 \% \mathrm{H}_{2} \mathrm{SO}_{4}$ for $3 \mathrm{~h}$ and then triple rinsing with $80^{\circ} \mathrm{C}$ distilled $\mathrm{H}_{2} \mathrm{O}$ before drying at $104^{\circ} \mathrm{C}$ for $3 \mathrm{~h}$ (AOAC International, 2005b). Ash was determined following combustion in a muffle furnace (Nabertherm $\mathrm{GmbH}$, Lilienthal, Germany) at $550^{\circ} \mathrm{C}$ for $5 \mathrm{~h}$ (AOAC International, 2005a). Starch was determined using the Megazyme Total Starch Assay Procedure (product no. K-TSTA, Megazyme International Ireland Ltd., Wicklow, Ireland; AOAC International, 2005d). Gross energy was determined by bomb calorimetry (Parr 1281 bomb calorimeter, Parr Instrument Company, Moline, IL), whereas ether extract was determined using Soxtex instruments (Tecator, Hoganas, SE) and light petro- 
leum ether. The $\mathrm{N}$ content of pasture, concentrate, milk, and feces samples was determined by combustion (FP 528 Analyzer, Leco Corp., St. Joseph, MI; AOAC International, 2005c). In vitro DM digestibility of pasture and concentrates offered was determined using a modification of Tilley and Terry (1963) for use in the Ankom Daisy (Ankom Technology). The P content of pasture, feces, and milk was determined by solubilizing the residual ash of each sample in concentrated aqua regia. The resulting solutions were then diluted 1 in 2 (milk), 1 in 10 (concentrate and pasture), or 1 in 20 (feces) with deionized $\mathrm{H}_{2} \mathrm{O}$. Two milliliters of the diluent was then combined with $2 \mathrm{~mL}$ of molybdovanadate reagent and allowed to stand for 15 min before analysis on photospectrometer (AOAC International, 2000).

Concentrations of milk fat, protein, lactose, casein, fatty acids, SCC, and urea were determined in a commercial milk laboratory (Independent Milk Laboratories, Cavan, Ireland) using mid infrared spectrophotometry (CombiFoss 5000, Foss Analytical A/S, Hillerød, Denmark). Blood samples were analyzed in a commercial laboratory (NUVET, University of Nottingham, Nottingham, UK). Blood samples were tested for bilirubin, BHB, NEFA, GGT, GLDH, glucose, urea, and P using Randox kits according to manufacturer's instructions using a RX IMOLA analyzer (Randox Laboratories, Antrim, UK). Samples of rumen fluid were allowed to thaw for $16 \mathrm{~h}$ at $4^{\circ} \mathrm{C}$ then centrifuged at $2,100 \times g$ for 10 min at $4^{\circ} \mathrm{C}$ before analyzing for $\mathrm{NH}_{3} \mathrm{~N}$ and VFA as described previously in Whelan et al. (2012). n-Alkanes were extracted from pasture, concentrate, and feces samples according to Dove and Mayes (2006). Following extraction, samples were analyzed for concentrations of individual n-alkanes using gas chromatography (Varian Inc., Palo Alto, CA) fitted with a 30-m capillary column with an internal diameter of $0.53 \mathrm{~mm}$ coated with $0.5 \mu \mathrm{m}$ of dimethyl polysiloxane (SGE Analytical Science Pty Ltd., Ringwood, Victoria, Australia).

\section{Statistical Analyses}

Data were checked for adherence to the normal distribution and homogeneity of variance using histograms and formal statistical tests as part of the Univariate procedure (SAS Institute Inc., 2004). Analysis of data was conducted using a mixed model procedure (SAS Institute Inc., 2004) including tests for the fixed effects of treatment, week, parity, and their interactions. Where interactions were not significant, this term was excluded from the final model. Statistically significant differences between least squares means were determined using the PDIFF command incorporating the Tukey test for pairwise comparison. Statistical significance was assumed at a value of $P<0.05$ and a tendency toward significance assumed at a value of $P$ $>0.05$ but $<0.10$.

\section{RESULTS}

\section{DMI, Milk Production, BW, and BCS}

Intake of pasture $(P=0.89)$ and total DMI $(P=$ $0.99)$ were not different among treatments. Similarly, there was no effect of by-product inclusion level on milk yield $(P=0.76)$, milk fat $(P=0.48)$, or protein concentration $(P=0.86)$. Concentrations of milk casein $(P=$ $0.86)$, urea $(P=0.61)$, and SFA $(P=0.84)$ were also not affected by by-product inclusion level. However, UFA were lower in the milk of cows offered BP35 and BP55 compared with those offered BP75 and BP95 ( $P$ $=0.05$, Table 2). Body weight (average starting and end $\mathrm{BW} ; 543.5$ and $585.5 \mathrm{~kg}$, respectively) and BCS (average starting and end BCS; 2.72 and 2.72, respectively) did not differ between treatments $(P=0.89$ and $P=0.22$, respectively) .

\section{Nutrient Partitioning, Rumen Fermentation, and Metabolic Status}

As with the milk production variables, supplementary concentrate type did not affect $\mathrm{N}$ or $\mathrm{P}$ intake $(P$ $=0.98$ and 0.99 , respectively, Table 3), excretion of $\mathrm{N}$ or $\mathrm{P}$ in the urine $(P=0.99$ and 0.97 , respectively), feces $(P=0.93$ and 0.89 , respectively), or milk $(P=$ 0.82 and 0.90 , respectively). Rumen VFA $(P=0.29)$ and $\mathrm{NH}_{3} \mathrm{~N}(P=0.98)$ were also not different among treatments. The blood metabolites (Table 4$)$ glucose $(P$ $=0.15)$, GGT $(P=0.47)$, GLDH $(P=0.71)$, bilirubin $(P=0.87)$, NEFA $(P=0.94)$, and BHB $(P=0.13)$ were not affected by concentrate type. Similarly, blood $\mathrm{P}$ was not affected by concentrate type $(P=0.43)$. However, blood urea N concentrations were higher in cows offered BP35 compared with those offered BP75 $(P=0.04$, Table 4).

\section{DISCUSSION}

\section{Nutrient Intake, Milk Production, and Composition}

No differences in grass intakes were observed (15.8 $\mathrm{kg}$ of DM) in this study, perhaps because animals were grazed as one group and pasture allocation was generous to avoid restriction. The contribution of pasture and concentrates to DMI was 75:25 across all treatments as intakes of concentrates were similar $(5.35 \mathrm{~kg}$ of DM). The concentrates offered were formulated to be isonitrogenous but they did vary significantly in starch and NDF content with BP35 and BP95 containing 0.28 
Table 2. The effect of supplementary concentrate type on DMI and milk production parameters ${ }^{1}$

\begin{tabular}{|c|c|c|c|c|c|c|}
\hline Item & BP35 & BP55 & BP75 & BP95 & SEM & $P$-value \\
\hline \multicolumn{7}{|l|}{ DMI (kg/d) } \\
\hline Pasture & 15.86 & 15.64 & 15.82 & 15.62 & 1.26 & 0.99 \\
\hline Concentrate & 5.35 & 5.33 & 5.42 & 5.31 & 1.01 & 0.89 \\
\hline \multicolumn{7}{|l|}{ Milk production (kg/d) } \\
\hline Milk & 30.61 & 31.90 & 30.18 & 30.63 & 1.76 & 0.76 \\
\hline Fat & 1.04 & 1.08 & 1.06 & 1.10 & 0.07 & 0.82 \\
\hline Fat & 3.40 & 3.43 & 3.55 & 3.57 & 0.14 & 0.48 \\
\hline SFA & 2.16 & 2.10 & 2.17 & 2.19 & 0.1 & 0.84 \\
\hline UFA & 1.13 & 1.12 & 1.19 & 1.20 & 0.04 & 0.05 \\
\hline Protein & 3.24 & 3.26 & 3.27 & 3.22 & 0.06 & 0.86 \\
\hline Casein & 2.52 & 2.54 & 2.56 & 2.52 & 0.05 & 0.86 \\
\hline Lactose & 4.48 & 4.51 & 4.49 & 4.47 & 0.03 & 0.62 \\
\hline Urea & 0.019 & 0.019 & 0.018 & 0.020 & 0.02 & 0.61 \\
\hline
\end{tabular}

${ }^{1} \mathrm{BP} 35=$ ration containing $35 \%$ by-products; BP55 = ration containing $55 \%$ by-products; BP75 = ration containing $75 \%$ by-products; BP95 = ration containing $95 \%$ by-products.

Table 3. Effect of supplementary concentrate type on partitioning of nitrogen ${ }^{1}$

\begin{tabular}{lcccccc}
\hline $\begin{array}{l}\text { Nitrogen } \\
(\mathrm{kg} / \mathrm{d})\end{array}$ & BP35 & BP55 & BP75 & BP95 & SEM & $P$-value \\
\hline Intake & 0.618 & 0.620 & 0.602 & 0.622 & 0.050 & 0.98 \\
Milk & 0.171 & 0.161 & 0.163 & 0.173 & 0.016 & 0.82 \\
Feces & 0.193 & 0.201 & 0.195 & 0.197 & 0.014 & 0.93 \\
Urine & 0.249 & 0.258 & 0.259 & 0.259 & 0.023 & 0.99 \\
\hline
\end{tabular}

${ }^{1}$ BP35 = ration containing $35 \%$ by-products; BP55 = ration containing $55 \%$ by-products; BP75 = ration containing $75 \%$ by-products; BP95 = ration containing $95 \%$ by-products.

Table 4. Effect of supplementary concentrate type on nutrient digestibility, rumen fermentation, and blood metabolites ${ }^{1}$

\begin{tabular}{|c|c|c|c|c|c|c|}
\hline Item & BP35 & BP55 & BP75 & BP95 & SEM & $P$-value \\
\hline Ash & 30.8 & 29.6 & 26.1 & 35.5 & 5.40 & 0.41 \\
\hline $\mathrm{NDF}$ & 68.8 & 67.8 & 67.9 & 71.6 & 2.40 & 0.34 \\
\hline Gross energy & 72.9 & 71.7 & 71.3 & 72.1 & 1.20 & 0.58 \\
\hline \multicolumn{7}{|l|}{ Rumen fermentation (mmol/L) } \\
\hline Acetate & 34.85 & 36.45 & 36.93 & 34.89 & 1.05 & 0.62 \\
\hline Isovalerate & 0.86 & 0.92 & 0.94 & 0.88 & 0.03 & 0.17 \\
\hline Isobutyrate & 0.59 & 0.62 & 0.61 & 0.60 & 0.04 & 0.93 \\
\hline Total VFA & 53.85 & 57.51 & 56.12 & 54.32 & 1.52 & 0.29 \\
\hline Rumen $\mathrm{NH}_{3}$ & 2.44 & 2.44 & 2.40 & 2.49 & 0.17 & 0.98 \\
\hline Rumen pH & 6.56 & 6.50 & 6.54 & 6.51 & 0.03 & 0.47 \\
\hline \multicolumn{7}{|l|}{ Blood metabolites $(\mathrm{mmol} / \mathrm{L})$} \\
\hline Glucose & 3.38 & 3.37 & 3.35 & 3.33 & 0.24 & 0.15 \\
\hline \multicolumn{7}{|l|}{ Blood metabolites (IU/mL) } \\
\hline Gamma-glutamyl transferase & 18.20 & 18.84 & 17.63 & 20.70 & 2.07 & 0.47 \\
\hline Glutamate dehydrogenase & 28.71 & 34.92 & 30.02 & 28.01 & 6.48 & 0.71 \\
\hline
\end{tabular}

${ }^{\mathrm{a}-\mathrm{C}}$ Means within rows sharing common superscripts do not significantly differ, $P>0.05$.

${ }^{1} \mathrm{BP} 35=$ ration containing 35\% by-products; BP55 = ration containing $55 \%$ by-products; BP75 = ration containing $75 \%$ by-products; BP95 = ration containing $95 \%$ by-products. 
and 0.03 starch and 0.27 and $0.5 \mathrm{~g} / 100 \mathrm{~g}$ of DM NDF, respectively. Cows offered BP95 therefore consumed 1.3 $\mathrm{kg}$ more NDF and $1.3 \mathrm{~kg}$ less starch than cows offered BP35.

Although intake of starch and NDF were quite different between BP35 and BP95 (0.30 and 0.06 starch and 0.67 and $0.91 \mathrm{~g} / 100 \mathrm{~g}$ of DM NDF, respectively), this did not appear to have an effect on the production of milk fat or protein. Previously, Van Knegsel et al. (2007) reported reduced milk fat production where lipogenic nutrients were replaced with glucogenic nutrients in the diet. The same study suggested that lower supply of acetate as a result of higher dietary starch content may contribute to lower concentrations of milk fat. In contrast, Whelan et al. (2014) reported higher acetate production in cows offered a high starch diet but with no effect on milk fat concentration. Production of VFA in the rumen depends on the substrates consumed by the animal and their relative utilization rate (Bannink et al., 2006). Results of this study show no differences in rumen VFA concentration as a result of differing starch and NDF levels in the concentrates offered. Consequently, no effects on milk fat yield or milk fat concentration were observed. This is important because it demonstrates that pasture-fed cows yielding up to $30 \mathrm{~kg} \cdot \mathrm{d}^{-1}$ can be offered supplementary concentrates formulated almost exclusively from $\mathrm{SH}$, PKE, and DDGS without affecting milk production or composition.

Westwood et al. (2003) raised concerns over the occurrence of SARA in pasture-fed dairy cattle in New Zealand and identified possible links to laminitis and lameness. The suggested reasons for pasture-based diets contributing to SARA included high concentrations of rapidly fermentable carbohydrates and low levels of physically effective fiber in lush pastures. A study by O'Grady et al. (2008) on Irish dairy farms, showed that low and suboptimal rumen $\mathrm{pH}$ is prevalent in a subpopulation of grazing dairy herds. An alternative view on the findings of this study might be that high intakes of starch from barley-based concentrates are possible for dairy cows on grass without further challenging rumen pH. Reis and Combs (2000) concluded that mean ruminal $\mathrm{pH}$ was not affected by the amount of grain concentrate when fed twice daily, showing that grazing cows have good rumen buffering capacity.

\section{Blood Metabolites, Rumen Fermentation, Animal BW, and BCS}

The variation in nutrient content (in particular starch) between the dietary treatments was not large enough to alter the rumen parameters measured in the study. This may be due to the high proportion of pasture in the diet. In a similar study by Whelan et al. (2014), supplementary concentrate type offered at $5.17 \mathrm{~kg}$ of DM did not affect rumen fermentation parameters.

Average DIM at the start of this study was $64( \pm 24)$, a time that coincides with peak milk production and potentially challenges of energy balance for dairy cows (Mulligan and Doherty, 2008). No difference was found in BCS or BW between treatments, which is consistent with the lack of difference in BHB and NEFA concentrations between dietary treatments. It is likely that differences in energy balance did not occur in this study because the cows used were in mid lactation and no differences in DMI or milk production were observed.

Measurement of blood metabolites allows for the determination of more discrete differences in energy status (Al Ibrahim et al., 2010), and in the absence of a liver biopsy, indicates whether or not an animal may be suffering from fatty liver (West, 1990; Bobe et al., 2004). In this experiment, starch levels decreased as byproducts increased from 35 to $95 \%$ of the concentrate offered. However, this did not alter circulating glucose, consistent with the concentrations of propionate observed in the rumen. The increase in urea in the blood where BP75 was offered compared with BP35 indicates that glucose levels may have been maintained through increased use of NEAA for gluconeogenesis (Lemosquet et al., 2009). However, cows offered BP95 did not have higher blood urea compared with BP35.

\section{Nitrogen Excretion}

A major point of concern for many intensively managed agricultural systems with high external inputs is the low resource-use efficiency, especially for N (Spiertz et al., 2007). Diets in the current study were formulated to be isonitrogenous, and as intake of pasture and concentrates were similar between dietary treatments, no difference in $\mathrm{N}$ excretion was observed. Importantly, no difference was found between the ratio of urinary to fecal $\mathrm{N}$ excretion between the treatments with an average of 1.3:1. Urinary $\mathrm{N}$ excretion is of particular concern from an environmental perspective as it has greater potential for $\mathrm{N}$ loss as $\mathrm{NO}_{3-}$ (Pakrou and Dillon, 1995) and $\mathrm{NH}_{3}$ volatilization (Hyde et al., 2003). This study demonstrated that cows offered diets high in DDGS, $\mathrm{SH}$, and PKE have similar $\mathrm{N}$ excretion to soybean meal and barley-based diets, therefore implying no advantage or disadvantage in terms of environmental impact.

\section{Cost}

Feed costs represent a large proportion of total costs in the feeding of cattle for the production of meat and 
milk (Swanson et al., 2014). Therefore, finding more economical sources of supplementary feed is of critical importance, particularly in the post EU milk quota era where milk prices are volatile and costs must be kept as low as possible to maintain profitability (Dillon et al., 2008; Horan, 2014). At the time of this study, eliminating the inclusion of barley and soybean meal (BP95) from the concentrate reduced the cost of the concentrates by approximately $€ 0.04 / \mathrm{kg}$ compared with BP35. This offers the opportunity for cost saving at the farm level considering that the cheaper ration (BP95) did not have any negative effect on the production parameters measured.

\section{CONCLUSIONS}

Results from the current experiment demonstrate that increasing the inclusion levels of DDGS, SH, and $\mathrm{PKE}$ in the concentrate of pasture-fed dairy cows is possible without negatively affecting milk production, rumen fermentation, metabolic status of the dairy cow, or excretion of $\mathrm{N}$. This offers the opportunity for cost saving at the farm level considering that the cheaper ration (BP95) did not have any negative effect on the environmental parameters measured.

\section{ACKNOWLEDGMENTS}

This project was funded by the Irish Government under the National Development Plan 2007-2013. Additionally the authors acknowledge the contribution of the farm and laboratory staff at UCD Lyons Farm.

\section{REFERENCES}

Abdelqader, M. M., and M. Oba. 2012. Lactation performance of dairy cows fed increasing concentrations of wheat dried distillers' grains with solubles. J. Dairy Sci. 95:3894-3904.

Aikman, P. C., D. E. Beever, and D. J. Humphries. 2006. The effect of incremental replacement of wheat with soya hulls in diets for Jersey cows on lactational performance, diet digestibility and feeding behaviour. Livest. Sci. 104:23-32.

Al Ibrahim, R. M., A. K. Kelly, L. O'Grady, V. P. Gath, C. McCarney, and F. J. Mulligan. 2010. The effect of body condition score at calving and supplementation with Saccharomyces cerevisiae on milk production, metabolic status, and rumen fermentation of dairy cows in early lactation. J. Dairy Sci. 93:5318-5328.

AOAC International. 2000. 970.26. Determination of calcium and magnesium. Official Methods of Analysis, 17th ed. AOAC International, Gaithersburg, MD

AOAC International. 2005a. 942.05. Ash in animal feed. Official Methods of Analysis, 18th ed. AOAC International, Gaithersburg, MD.

AOAC International. 2005b. 973.18. Fiber (acid detergent) and lignin in animal feed. Official Methods of Analysis, 18th ed. AOAC International, Gaithersburg, MD.

AOAC International. 2005c. 990.03. Crude protein in animal feed. Official Methods of Analysis, 18th edition. AOAC International, Gaithersburg, MD.
AOAC International. 2005d. 996.11. Starch in animal feed. Official Methods of Analysis, 18th ed. AOAC International, Gaithersburg, MD.

Bannink, A., J. Koqut, J. Dijkstra, J. France, E. Kebreab, A. M. Van Vuuren, and S. Tamminga. 2006. Estimation of the stoichiometry of volatile fatty acid production in the rumen of lactating cows. J. Theor. Biol. 238:36-51.

Bobe, G., J. W. Young, and D. C. Beitz. 2004. Invited review: Pathology, etiology, prevention, and treatment of fatty liver in dairy cows. J. Dairy Sci. 87:3105-3124.

Casey, J. W., and N. M. Holden. 2005. Analysis of greenhouse gas emissions from the average Irish milk production system. Agric. Syst. 86:97-114.

Dias, F. N., J. L. Burke, D. Pacheco, and C. Holmes. 2008. Brief Communication: The effect of palm kernel expeller as a supplement for grazing dairy cows at the end of lactation. Proc. N.Z. Soc. Anim. Prod. 68:111-112.

Dillon, P., A. T. Hennessy, L. Shalloo, F. Thorne, and B. Horan. 2008. Future outlook for the Irish dairy industry: A study of international competitiveness, influence of international trade reform and requirement for change. Int. J. Dairy Technol. 61:16-29.

Dove, H., and R. W. Mayes. 2006. Protocol for the analysis of n-alkanes and other plant-wax compounds and for their use as markers for quantifying the nutrient supply of large mammalian herbivores. Nat. Protoc. 1:1680-1697.

Edmonson, A. J., I. J. Lean, L. D. Weaver, T. Farver, and G. Webster 1989. A body condition scoring chart for Holstein dairy cows. J. Dairy Sci. 72:68-78.

Ewing, W. 1998. The Feeds Directory. Context Publications, Leicestershire, UK.

Horan, B. 2014. Resilient farming systems for an expanding Irish dairy industry. Joint IGFA/Teagasc Nutrition Event. Teagasc, Cork, Ireland.

Hyde, B. P., O. T. Carton, P. O'Toole, and T. H. Misselbrook. 2003. A new inventory of ammonia emissions from Irish agriculture. Atmos. Environ. 37:55-62.

Ipharraguerre, I. R., R. R. Ipharraguerre, and J. H. Clark. 2002. Performance of lactating dairy cows fed varying amounts of soyhulls as a replacement for corn grain. J. Dairy Sci. 85:2905-2912.

Kolver, E. 2006. PKE an economically priced supplement. Dexcelink Autumn 2006.

Lemosquet, S., G. Raggio, G. E. Lobley, H. Rulquin, J. Guinard-Flament, and H. Lappiere. 2009. Whole body glucose metabolism and mammary energetic nutrient metabolism in lactating dairy cows receiving digestive infusions of casein and propionic acid. J. Dairy Sci. 92:6068-6082.

Mayes, R. W., C. S. Lamb, and P. M. Colgrove. 1986. The use of dosed and herbage n-alkanes as markers for the determination of herbage intake. J. Agric. Sci. 107:161-170.

Mulligan, F. J., and M. L. Doherty. 2008. Production diseases of the transition cow. Vet. J. 176:3-9.

O'Grady, L., M. L. Doherty, and F. J. Mulligan. 2008. Subacute ruminal acidosis (SARA) in grazing Irish dairy cows. Vet. J. 176:44-49.

Pakrou, N., and P. Dillon. 1995. Preferential flow, nitrogen transformations and $15 \mathrm{~N}$ balance under urine-affected areas of irrigated and non-irrigated clover-based pastures. J. Contam. Hydrol. 20:329347.

Purcell, P. J., A. J. Dale, A. W. Gordon, J. Barley, and C. P. Ferris. 2016. Effects of predicted milk yields sustained by grazed grass on dairy cow performance and concentrate requirements throughout the grazing season. Grass Forage Sci. 71:389-402. https://doi. org $/ 10.1111 /$ gfs.12193.

Reis, R. B., and D. K. Combs. 2000. Effects of increasing levels of grain supplementation on rumen environment and lactation performance of dairy cows grazing grass-legume pasture. J. Dairy Sci. $83: 2888-2898$.

SAS Institute Inc. 2004. SAS Users Guide. 9.1.2 ed. 2004 SAS Institute Inc., Cary, NC.

S.I. 2010. S. I. 610. European Communities (Good Agricultural Practice For Protection Of Waters) Regulations 2010. In Statutory Instruments no. 610 of 2010. 
Schingoethe, D. J., K. F. Kalscheur, A. R. Hippen, and A. D. Garcia. 2009. Invited review: The use of distillers products in dairy cattle diets. J. Dairy Sci. 92:5802-5813.

Sinclair, K. D., P. C. Garnsworthy, G. E. Mann, and L. A. Sinclair. 2014. Reducing dietary protein in dairy cow diets: Implications for nitrogen utilization, milk production, welfare and fertility. Animal $8: 262-274$

Spiertz, J. H. J., P. C. Struik, and H. H. van Laar. 2007. Scale and Complexity in Plant Systems Research: Gene-Plant-Crop Relations. Springer, Dordrecht, the Netherlands.

Swanson, K. C., A. Islas, Z. E. Carlson, R. S. Goulart, T. C. Gilbery, and M. L. Bauer. 2014. Influence of dry-rolled corn processing and increasing dried corn distillers grains plus solubles inclusion for finishing cattle on growth performance and feeding behavior. J. Anim. Sci. 92:2531-2537.

Tilley, J. M. A., and R. A. Terry. 1963. A two-stage technique for the in vitro digestion of forage crops. Grass Forage Sci. 18:104-111.

Van Knegsel, A. T. M., H. Van den Brand, J. Dijkstra, and B. Kemp. 2007. Effects of dietary energy source on energy balance, metabo- lites and reproduction variables in dairy cows in early lactation. Theriogenology 68(E-Suppl. 1):S274-S280 (Abstr.)

Van Soest, P. J., J. B. Robertson, and B. A. Lewis. 1991. Methods for dietary fiber, neutral detergent fiber, and nonstarch polysaccharides in relation to animal nutrition. J. Dairy Sci. 74:3583-3597.

West, H. J. 1990. Effect on liver function of acetonaemia and the fat cow syndrome in cattle. Res. Vet. Sci. 48:221-227.

Westwood, C. T., E. Bramley, and I. L. Lean. 2003. Review of the relationship between nutrition and lameness in pasture-fed dairy cattle. N. Z. Vet. J. 51:208-218.

Whelan, S. J., F. J. Mulligan, V. Gath, B. Flynn, and K. M. Pierce. 2014. Short communication: Effect of dietary manipulation of crude protein content and nonfibrous-to-fibrous-carbohydrate ratio on energy balance in early-lactation dairy cows. J. Dairy Sci. 97:7220-7224.

Whelan, S. J., K. M. Pierce, B. Flynn, and F. J. Mulligan. 2012 Effect of supplemental concentrate type on milk production and metabolic status in early-lactation dairy cows grazing perennial ryegrass-based pasture. J. Dairy Sci. 95:4541-4549. 